\title{
Energy, nutrients and food sources in snacks for adolescents and young adults
}

\section{Energia, nutrientes e fontes alimentares em lanches de adolescentes e jovens adultos}

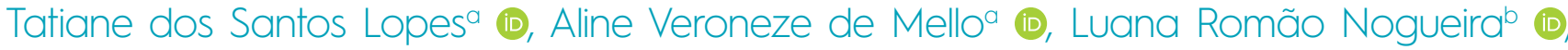 \\ Ana Carolina Barco Leme ${ }^{a, b, c}$ (D), Regina Mara Fisberg ${ }^{a, *}$
}

\section{ABSTRACT}

Objective: To evaluate associations between snacking and energy, nutrients and food source, and to identify the contribution of snacking across age, sex, weight status and lifestyle behaviors among adolescents and young adults.

Methods: A sub-sample was calculated from the population-based cross-sectional study 2015-Health Survey of São Paulo (ISA-Capital). The survey "ISA-Nutrição" used a sample of non-institutionalized individuals aged $>15$ years. For this study, only adolescents (1218 years old; $n=418$ ) and young adults ( $19-29$ years old; $n=218$ ) were included. Snacks were identified, and their contribution to energy, nutrients, and food sources were calculated. Descriptive statistics and logistic regressions were used.

Results: Participants experienced an average of $2.9 \pm 0.6$ snacking occasions per day. Young adults consumed more energy from morning and night snacks, and adolescents, from afternoon snacks. The top three food sources on snacking contributed to $30.5 \%$ of energy: cookies (11.8\%), sugar sweetened beverages (9.4\%), sweets and other desserts (9.3\%). Although results were non-significant, being a female (Odds Ratio [OR] 0.93; 95\% confidence interval $[95 \% \mathrm{Cl}] 0.36-1.49)$, meeting the physical activity recommendations (OR $0.75 ; 95 \% \mathrm{Cl} 0.25-1.25$ ), and scoring higher for the healthy eating index (OR 0.88; $95 \% \mathrm{C}$ $0.24-1.52$ ) were all factors related to increased intake of snacks. Alternatively, overweight individuals (OR $-0.54 ; 95 \% \mathrm{Cl}-1.00$ to -0.08) consumed less snacks.

Conclusions: Improving the quality of snacks should be considered in behavior-change strategies.

Keywords: Eating; Snacks; Adolescent; Young adult.

\section{RESUMO}

Objetivo: Avaliar associações entre lanches e consumo de energia, nutrientes e fontes alimentares e identificar seus contribuintes por idade, sexo, status de peso e comportamentos de estilo de vida entre adolescentes e jovens adultos.

Métodos:Subamostra calculada a partir do estudo de base-populacional transversal Inquéritos de Saúde de São Paulo (ISA-Capital, 2015). O ISA-Nutrição utilizou amostra de indivíduos não-institucionalizados com idade $>15$ anos. Para este estudo, apenas adolescentes (12-18 anos; $n=418$ ) ejovens adultos (19-29 anos; $n=218$ ) foram incluídos. Os "lanches" foram definidos, bem como foram calculadas a contribuição de energia e nutrientes, e as fontes alimentares. Estatística descritiva e regressões logísticas foram utilizadas.

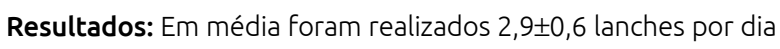
pelos participantes. Jovens adultos consumiram mais energia nos lanches da manhã e noite, enquanto adolescentes, à tarde. As três principais fontes de alimentos nos lanches contribuíram em $30,5 \%$ para o total de energia: biscoitos $(11,8 \%)$, bebidas açucaradas (9,4\%), e doces e outras sobremesas (9,3\%). Apesar de os resultados não serem significantes, ser do sexo feminino (Odds Ratio[OR] 0,93, intervalo de confiança de 95\% [IC95\%] 0,36-1,49), atingir as recomendações de atividade física (OR 0,75, IC95\% 0,25$1,25)$, e ter alta pontuação no índice do total da qualidade dieta (OR 0,88, IC95\% 0,24-1,52) resultou em aumento na ingestão de lanches. Alternativamente, ter sobrepeso (OR -0.54, IC95\% - 1.00 a -0.08) está relacionado a menores chances de consumir lanches. Conclusões: Estratégias para melhorar a qualidade dos lanches deveriam ser consideradas nas intervenções de mudança de comportamentos.

Palavras-chave: Ingestão de alimentos; Lanches; Adolescente; Adulto jovem.

*Corresponding author. E-mail: regina.fisberg@gmail.com (R.M. Fisberg).

aniversidade de São Paulo, São Paulo, SP, Brazil.

'Centro de Excelência em Dificuldades Alimentares, Instituto de Pesquisa e Ensino em Saúde Infantil, São Paulo, SP, Brazil. 'Family Relations and Applied Nutrition, University of Guelph, Canada.

Received on May 16, 2020; approved on September 20, 2020. 


\section{INTRODUCTION}

While non-modifiable (i.e., genetics and other biological) mechanisms are partly the blame, modifiable risk factors (e.g., eating behaviors) are considered the primarily root in the genesis of obesity. ${ }^{1,2}$ Obesity is a significant public health concern because of its increase prevalence and adverse effects on psychosocial and physical health. ${ }^{3,4}$ Adolescents and adults had a higher overweight prevalence and older adults were higher for being obese. ${ }^{5}$

Evidence shows that Brazilian adolescents and young adults are failing to meet current dietary recommendations of healthy eating, ${ }^{6}$ being more pronounced among adolescents from low-income families, and with ethnic/racially diverse backgrounds. ${ }^{7}$ Over the past decades, practitioners and policy makers have been worried about the increase frequency of snacking, i.e., in-between meals, their daily energy intake, and food and beverages sources consumed as snacks. Adolescents consumed roughly one-third of total daily energy intake from snacks. ${ }^{8}$ In adults, snacking occasions and total energy intakes has been increasing, while substituting lean meats and dairy food sources has been observed. ${ }^{9}$ Therefore, considerable contribution of snacking to adolescents and adults' total energy intake are needed to comprehend how snacks contribute to weight status and other lifestyle behaviors. ${ }^{9} 10$

Snacking has been defined and measured in variety of ways. Most common definition is based on the intake of energy-dense food sources. The inconsistent definitions are crucial to recognize when interpreting the results on snack studies. A review has defined snacks into three main factors, to allow differentiation from the main meals:

1. consumers' perceptions, considering main meals vs. other eating occasions as snacks;

2. time of consumption based on the time slots for breakfast, lunch, and, dinner, and the other times are considered snacks; and

3. energy intake, snacks should be $<15 \%$ of total energy intake. Moreover, distinction must be made in terms of dietary composition. ${ }^{11}$ Differences between industrialized and developing countries in terms of snacking food sources have been shown, an increased intake on savory snacks and sugar-sweetened beverages (SSB). Alternatively, snacks can provide an opportunity to supplement the diet where foods in meals are not adequately consumed. Eating a fruit as a mid-morning snack is a good way to meet the recommended intake of fruits, along with those eaten at meals. ${ }^{11}$

There is a gap on studies that explore the percussion of snacking on food consumption, weight-status, and other lifestyle behaviors, especially among racial/ethnically diverse and low-income individuals. Additionally, most studies conducted have been concentrated on school-age children from high-income countries and in identifying intakes on particularly nutrients (e.g., added sugars and saturated fats), or on the intake of specific food groups (e.g., SSB and savory snacks), so, little attention has been given on understanding the contribution of snacks on diet for other age groups, at a population level, in low- to middle-income countries. Hence, this study aimed to evaluate associations of snacking with Brazilian adolescents and adults' energy and nutrient intakes, as well as food sources. A second aim was to identify differences in the contribution of snacks to the population dietary intake across age groups, sex, weight status, and lifestyle behaviors.

\section{METHOD}

Data from the 2015 Health Survey of São Paulo (acronym in Portuguese "ISA-Capital") were used. The ISA-Capital is a population-based, cross-sectional survey that uses a multistage stratified area probability sample of non-institutionalized individuals, that provides nationally representative estimates of the population of the city of São Paulo, Brazil. Briefly, the survey examined approximately 3,300 individuals in $2003(\mathrm{n}=3,357)$, $2008(n=3,271)$, and $2015(n=4,059)$. Data were collected by trained interviewers using a questionnaire, divided into sixteen blocks; of these, only two were used: health-related behaviors, including eating, physical activity (PA) and sedentary behaviors; and socio-demographic characteristics.

In order to collect information about diet and nutrition, a sub-sample from the ISA-2015 was calculated. This sub-sample was named ISA-Nutrition (Health Survey of Sáo Paulo with focus on Nutrition), in which 554 adolescents, 254 young adults, 390 adults, and 545 older adults randomly selected participated for a dietary data collection and further phases of the ISA-Nutrition. Additional details about this sub-sample study were previously published. ${ }^{12}$ The Institutional Review Boards from the School of Public Health, University of São Paulo and the Department of Health from the city Hall of Sáo Paulo approved the ISA-Capital study, as well as the present study. Participants provided written informed consent and assent forms prior to their participation in the study.

The World Health Organization (WHO) defines adolescents as individuals aged between 10 and 19 years of age, ${ }^{13}$ and young adults have been defined in some studies ${ }^{14}$ as people aged 18 to 35 years. Therefore, data from adolescents and young adults aged 12 to 35 years old participating in the ISANutrition were used, resulting in a final analytic sample of 636 (418 adolescents and 218 young adults) after exclusion 
of subjects not meeting this study criteria. They were excluded if their intake of foods and beverages were below or above their usual intake reported on $24 \mathrm{~h}$ dietary recall $(24 \mathrm{hR})$, with the following questions asked: (a) "Were foods and beverages consumed yesterday the same as what you usually eat?" yes or no, why; and (b) Do you consider that the amount eaten yesterday was: (a) less (b) same (c) more than usually eaten? Individuals older than 30 years, pregnant women and lactating women, and individuals who did not report any food intake in the $24 \mathrm{hR}$ were also excluded. Socio-demographic information and self-reported physical activity levels were determined from the ISA-Capital survey. Physical activity was classified into two levels: meeting and not meeting the WHO guidelines for $\mathrm{PA}^{15}$ to the individuals' intensity level in a typical week. The ISA-Capital employs protocols and procedures that ensure confidentiality and protect individual participant identification.

Dietary data was collected from two $24 \mathrm{hR}$ in non-consecutive days, representing different week and weekend days and seasons of the year. The first $24 \mathrm{hR}$ was collected in home visits and the second with telephone interviews using the Automated Multiple Pass Method. ${ }^{16}$ The Nutrition Data System for Research (NDS-R, version 2014) was used to calculate energy and nutrients collected from the dietary recalls. As the NDS-R uses the United States Department of Agriculture food composition database, the energy and nutrient values provided in our study were compared to other Brazilian food composition databases. ${ }^{17}$

Foods and beverages that most contributed to snack total energy-intake were identified and grouped based on nutritional values, eating frequency and other diet habits from individuals living in São Paulo. Foods and beverages consumed by less than $2 \%$ of the study sample were not grouped because of the high variability in terms of nutrient values. The energy contributing to each group was determined based on the method proposed by Block et al. ${ }^{18}$

"Snack" was defined as the type of meal self-reported by participants. All participants reported snacking in ISA-Capital. Snacks were consistent with definitions previously published in the literature. ${ }^{11}$ Thus, this moment is considered an eating occasion other than breakfast, lunch, and dinner, which are known to take place commonly between 6-10am, 12-3pm, and 7-9pm, respectively, and it is comprised of all type of food and beverages, except water. Statistical modeling techniques incorporated in the Multiple Source Method (MSM) software were done to provide usual dietary intake adjusted for intra-personal variance of energy and nutrients intake, taking into account the information provided on the two $24 \mathrm{hR}$. Sodium and added sugar were calculated as terciles of intake, classified as low, medium, and high. ${ }^{19}$ The overall diet quality of the sample was calculated based on the Brazilian Healthy Eating Index-Revised (BHEI-R), ${ }^{20}$ and categorized in terciles of intake.

Height and weight were measured using procedures outlined in the ISA-Capital protocol. ${ }^{12}$ The body mass index (BMI) was calculated for adolescents according to BMI $Z$ scores for age and sex: $\leq+1 Z$ score were non-overweight and $>+1 Z$ score were classified as overweight or obese. Young adults ( $\geq 19$ years old) were classified according to the WHO's standards, with BMI $<24.99 \mathrm{~kg} / \mathrm{m}^{2}$ as non-overweight and BMI $>25 \mathrm{~kg} / \mathrm{m}^{2}$ as overweight. Overweight and obese individuals were combined, like in previous studies. ${ }^{21}$

The International Physical Activity Questionnaire (IPAQ) long-version ${ }^{22}$ adapted for the Brazilian reality ${ }^{23}$ was assessed for PA duration, frequency, and intensity during leisure, work/ school time, transportation, and household tasks. the information was dichotomized as meeting or not meeting WHO's PA guidelines: adolescents (12-18 years old) should be at least 300 minutes/week and adults ( $\geq 19$ years) at 150 minutes/week. ${ }^{15}$

The time spent watching TV and using computers (or other screen devices, such as mobile phones, and tablets) was assessed in two questions. For each type of screen-time recreation, the participants were to report daily average hours during the weekdays and the weekends. The cut-off point for not being sedentary was less than two hours/day, according to the literature. ${ }^{24}$

Socio-demographic variables included sex, age group (adolescents vs. young adults), ethnicity (Caucasian and NonCaucasian), educational level of the head of the family (middle school, high school, and some college/university degree), income status ( $\leq 1$ and $<1$ minimum wage), smoking, and alcohol intake.

Descriptive statistics were conducted using mean (standard error) for continuous variables, and frequency (\% and $95 \% \mathrm{CI})$ for categorical variables. The Wald test was used to compare energy intake to socio-demographic and lifestyle behaviors, as well as the meal energy intake of participants. Multiple logistic regression models adjusted for the socio-demographic data and presence of chronic non-communicable diseases were performed to examine associations between socio-demographic features, weight-status, and lifestyle behaviors, including snacks intake. Snacks intake were categorized as $\leq 1$ snack/day or $>1$ snack/day. All analyses were conducted in the software STATA 14.0 (Stata Corp, Texas, USA), with sample weights considering the complex survey design and with significance levels set at $\mathrm{p}<0.05$.

\section{RESULTS}

Adolescents and young adults in the study sample were between 12 and 29 years of age. The study sample ( $\mathrm{n}=636)$ was composed 
by $52.6 \%$ of boys, most of them being non-Caucasian (59.1\%), and $53.7 \%$ receiving less than 1 minimum wage/month, i.e., considered vulnerable in terms of socio-economic status (SES). As for the head of the family education background, most of them had only basic education degree (43.7\%), followed by high-school (35.7\%) and higher education (20.6\%). Almost $70 \%$ of the participants were not overweight/obese, $71.1 \%$ of them did not meet the recommendations for PA and $87.9 \%$ of them spent more than 2 hours/day on screens. Other lifestyle behaviors, such as smoking (or former smoking) were seen only in $11.9 \%$ of the sample, while alcohol intake was present in $24.6 \%$ of the population studied. Additional details are shown in Table 1.

Young adults have a slightly higher energy intake (EI) $(2118.9 \mathrm{kcal} /$ day) than adolescents $(2093.9 \mathrm{kcal} /$ day $)$, but there were no significant differences. Young adults have a significant higher EI in mid-morning (119.6kcal/day) and night (119.6kcal/day) snacks, with 36.4 vs. $103.5 \mathrm{kcal} /$ day for adolescents. However, adolescents have a significant higher EI in mid-afternoon snacks $(255.1 \mathrm{kcal} /$ day $)$ compared to young adults (248.9kcal/day) (Figure 1).

Participants had on average $2.9 \pm 0.2$ snack times per day; each occasion contributed to a mean of $38.3 \pm 0.3 \mathrm{kcal}$ in morning snacks, $252.0 \pm 1.2 \mathrm{kcal}$ in afternoon snacks, and $111.5 \pm 2.1 \mathrm{kcal}$ in night snacks. Males have a significant higher energy intake in afternoon snacks (247.5 \pm 1.2 vs. $256.1 \pm 1.9$ females) and night snacks ( $130.1 \pm 3.0$ vs. $90.9 \pm 2.2 \mathrm{kcal} /$ day females), but females showed a higher energy intake in morning snacks (39.3 \pm 0.4 vs. $37.3 \pm 0.4 \mathrm{kcal} /$ day males). Young adults showed higher intake in morning snacks $(40.2 \pm 0.5 \mathrm{kcal} / \mathrm{day})$ and night snacks $(103.5 \pm 0.9 \mathrm{kcal} /$ day) compared to adolescents showing respectively, $36.4 \pm 0.2$ and $103.5 \pm 2.2 \mathrm{kcal} /$ day. Adolescents had a significant higher intake in afternoon snacks $(255.1 \pm 1.4$ vs. $248.9 \pm 1.9 \mathrm{kcal} /$ day). Individuals who spent more than two hours on screens showed an increased energy intake in afternoon snacks ( $253.2 \pm 1.1$ vs. $243.4 \pm 4.9 \mathrm{kcal})$. There were no significant differences between weight status and physical activity as for energy intake in snack occasions. Data is available upon request for details on snack occasions in relation to socio-demographic features and lifestyle behaviors.

Table 2 shows snacks presenting nutrients of public concern, with mean differences between subjects. Young adults vs. adolescents had a significant higher intake of carbohydrates ( 1057.3 vs. $1008.1 \mathrm{kcal})$, proteins $(362.9$ vs. $319.2 \mathrm{kcal})$, total fats $(712.0$ vs. $678.2 \mathrm{kcal})$, fiber ( 15.1 vs. $14.5 \mathrm{grams})$, calcium ( 830.2 vs. $607.8 \mathrm{mg}$ ) and sodium (3602.8 vs. $3238.0 \mathrm{mg}$ ). Added sugars and iron intake was higher among adolescents than among young adults, respectively, 284.7 vs. $271.9 \mathrm{kcal}$ and 37.7 vs. $20.9 \mathrm{mg}$.
The top 20 food sources contributing to energy intake from snacks of all study participants and separated by age groups are listed in Table 3. The five most common food sources for all

Table 1 Socio-demographic and lifestyle characteristics among adolescents ( $n=418)$ and young adults $(n=218)$ from the 2015 ISA-Capital study.

\begin{tabular}{|c|c|c|c|}
\hline Characteristics & $\mathrm{n}$ & $\%$ & $95 \% \mathrm{Cl}$ \\
\hline \multicolumn{4}{|l|}{ Sex } \\
\hline Males & 330 & 52.6 & $48.0-57.2$ \\
\hline Females & 306 & 47.4 & $42.9-52.0$ \\
\hline \multicolumn{4}{|l|}{ Age group (years) } \\
\hline $12-18$ & 418 & 51.7 & $47.2-56.1$ \\
\hline 19-29 & 218 & 48.4 & $44.0-52.8$ \\
\hline \multicolumn{4}{|l|}{ Ethnicity } \\
\hline Caucasian & 254 & 40.9 & $36.0-45.9$ \\
\hline Non-Caucasian & 375 & 59.1 & $54.1-64.0$ \\
\hline \multicolumn{4}{|l|}{ Income per capitaa } \\
\hline$\leq 1 \mathrm{MW}$ & 339 & 53.7 & $47.1-60.2$ \\
\hline$>1 \mathrm{MW}$ & 161 & 31.2 & $26.0-37.0$ \\
\hline NR & 97 & 15.1 & $9.8-22.5$ \\
\hline
\end{tabular}

Educational level of the head of the family

\begin{tabular}{l|l|l|l}
\hline Middle school & 282 & 43.7 & $38.1-49.5$ \\
\hline High school & 201 & 35.7 & $31.0-40.7$ \\
\hline Higher education & 112 & 20.6 & $16.1-26.0$ \\
\hline Weight status & 432 & 69.9 & $65.2-74.2$ \\
\hline Normal weight & 184 & 30.1 & $25.8-34.8$ \\
\hline Overweight or obese &
\end{tabular}

Physical activity level

\begin{tabular}{|c|c|c|c|}
\hline $\begin{array}{l}\text { Does not meet } \\
\text { recommendation }\end{array}$ & 465 & 71.2 & $66.6-75.4$ \\
\hline Meets recommendation & 166 & 28.8 & $24.6-33.4$ \\
\hline \multicolumn{4}{|l|}{ Time spent on screens } \\
\hline$\leq 2$ hours/day & 78 & 12.0 & $9.3-15.5$ \\
\hline$>2$ hours/day & 558 & 88.1 & $84.5-90.7$ \\
\hline \multicolumn{4}{|l|}{ Smoking habits } \\
\hline Never smoke & 572 & 88.1 & 84.9-90.8 \\
\hline Former smoker or smoker & 62 & 11.9 & $9.2-15.2$ \\
\hline \multicolumn{4}{|l|}{ Alcohol intake } \\
\hline Does not drink & 517 & 75.4 & $70.3-79.8$ \\
\hline Drink & 117 & 24.6 & $20.2-29.7$ \\
\hline
\end{tabular}

aMinimum wage in the year of 2015 in Brazil was R\$788,00 (Brazilian currency). The conversion rate at the time was 1 US Dollar=3,00 Brazilian Reais. 95\% Cl: 95\% confidence interval; NR: No reply; MW: monthly wage. 


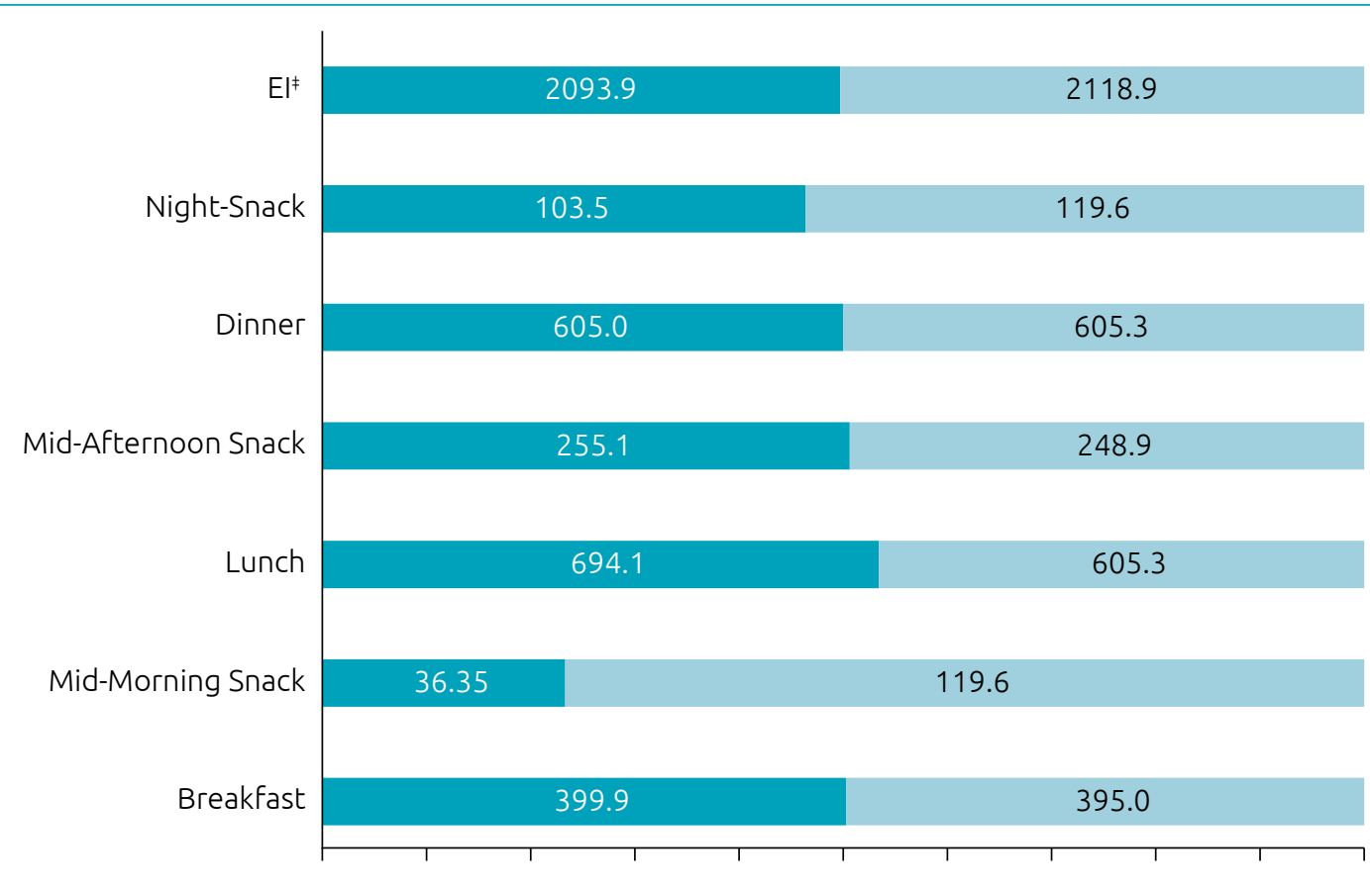

- TEl from meals and snacks - Adolescents $\quad$ - TEl from meals and snacks - Young Adults

El: energy intake; ”variables adjusted for sex, age, income, and usual food intake.

Figure 1 Average energy intake from meals and snacks among adolescents ( $n=418)$ and young adults $(n=218)$ from the 2015 ISA-Capital study.

Table 2 Differences in mean $(95 \% \mathrm{Cl})$ of macro and micronutrients in snacks by adolescents $(\mathrm{n}=418)$ and young adults ( $n=218$ ) living in the city of São Paulo. 2015 ISA-Capital.

\section{\begin{tabular}{l|l|l} 
Total Sample & Adolescents & Young adults
\end{tabular}}

Carbohydrates, mean $(95 \% \mathrm{Cl})$

\begin{tabular}{|c|c|c|c|c|c|c|}
\hline 9 & 257.7 & $(253.7-261.7)$ & 252.0 & $(247.2-256.8)$ & 264.3 & (257.9-270.8) \\
\hline kcal & 1030.8 & $(1014.7-1046.9)$ & 1008.0 & $(988.8-1027.2)$ & 1057.3 & $(1031.6-1083.1)$ \\
\hline \multicolumn{7}{|c|}{ Proteins, mean $(95 \% \mathrm{Cl})$} \\
\hline 9 & 84.8 & $(82.9-86.8)$ & 79.8 & $(77.5-82.0)$ & 90.7 & $(87.8-93.7)$ \\
\hline kcal & 339.4 & $(331.5-347.3)$ & 319.2 & $(310.1-328.2)$ & 362.9 & $(351.3-374.6)$ \\
\hline
\end{tabular}

Total fat, mean $(95 \% \mathrm{Cl})$

\begin{tabular}{l|c|c|c|c|c|c|c}
\hline$g$ & 77.1 & $(75.6-78.5)$ & 75.4 & $(73.6-77.1)$ & $\mathbf{7 9 . 1}$ & $\mathbf{( 7 6 . 8 - 8 1 . 4 )}$ \\
\hline $\mathrm{kcal}$ & 693.8 & $(680.8-706.9)$ & 678.2 & $(662.4-693.9)$ & $\mathbf{7 1 2 . 0}$ & $\mathbf{( 6 9 1 . 6 - 7 3 2 . 5 )}$ \\
\hline Added sugars, mean $(95 \% \mathrm{Cl})$ & \multicolumn{5}{|l}{} \\
\hline $\mathrm{g}$ & 69.7 & $(68.9-70.5)$ & $\mathbf{7 1 . 2}$ & $\mathbf{( 7 0 . 4 - 7 2 . 0 )}$ & 68.0 & $(66.8-69.2)$ \\
\hline $\mathrm{kcal}$ & 278.8 & $(275.8-281.9)$ & $\mathbf{2 8 4 . 7}$ & $\mathbf{( 2 8 1 . 4 - 2 8 8 . 1 )}$ & 272.0 & $(267.1-276.8)$ \\
\hline Fiber $(\mathbf{g})$, mean $(95 \% \mathrm{Cl})$ & 14.8 & $(14.5-15.0)$ & 14.5 & $(14.2-14.8)$ & $\mathbf{1 5 . 1}$ & $\mathbf{( 1 4 . 8 - 1 5 . 5 )}$ \\
\hline Calcium (mg), mean $(95 \% \mathrm{Cl})$ & 710.1 & $(689.4-731.6)$ & 607.8 & $(588.4-627.3)$ & $\mathbf{8 3 0 . 2}$ & $\mathbf{( 8 0 2 . 9 - 8 5 7 . 5 )}$ \\
\hline Iron (mg), mean $(95 \% \mathrm{Cl})$ & 30.0 & $(27.7-32.3)$ & $\mathbf{3 7 . 7}$ & $\mathbf{( 3 5 . 6 - 3 9 . 8 )}$ & 21.0 & $(17.3-24.7)$ \\
\hline Sodium (mg), mean $(95 \% \mathrm{Cl})$ & 3406.9 & $(3340.6-3473.2)$ & 3239.0 & $(3163.0-3314.9)$ & $\mathbf{3 6 0 2 . 8}$ & $\mathbf{( 3 5 0 3 . 0 - 3 7 0 2 . 6 )}$ \\
\hline
\end{tabular}

95\% Cl: 95\% confidence interval; variables adjusted for sex, age, income, and usual intake. Values in bold were significant ( $p<0.05)$. 
Table 3 Sources of energy intake from snacks consumed by adolescents ( $n=418)$ and young adults ( $n=218)$ living in the city of São Paulo. 2015 ISA-Capital.

\begin{tabular}{|c|c|c|c|c|c|c|}
\hline \multirow{2}{*}{ Rank } & Food groups & PCT & Food groups & PCT & Food groups & PCT \\
\hline & \multicolumn{2}{|l|}{ Total sample } & \multicolumn{2}{|l|}{ Adolescents } & \multicolumn{2}{|l|}{ Young adults } \\
\hline 1 & Cookies & 11.8 & Cookies & 15.0 & Sugar-sweetened beverages & 10.5 \\
\hline 2 & Sugar-sweetened beverages & 9.4 & Sweets and other desserts & 10.9 & Croquettes & 9.1 \\
\hline 3 & Sweets and other desserts & 9.3 & Breads & 9.5 & Cookies & 8.4 \\
\hline 4 & Breads & 8.9 & Sugar-sweetened Beverages & 8.5 & Bread & 8.3 \\
\hline 5 & Croquettes & 6.7 & Savory snacks & 6.0 & Sweets and other desserts & 7.7 \\
\hline 6 & Crackers & 5.4 & Fruits & 4.6 & Crackers & 6.4 \\
\hline 7 & Savory snacks & 4.5 & Croquettes & 4.5 & Cakes & 6.2 \\
\hline 8 & Savory bakery pastries & 4.4 & Butter and margarine & 4.4 & Alcoholic beverages & 5.2 \\
\hline 9 & Fruits & 4.3 & Crackers & 4.4 & Savory bakery pastries & 4.9 \\
\hline 10 & Cakes & 4.3 & Milk & 4.2 & Fruits & 4.1 \\
\hline 11 & Milk & 4.0 & Savory bakery pastries & 4.0 & Milk & 3.7 \\
\hline 12 & Butter and margarine & 3.3 & Non-processed meats & 2.7 & Non-processed meats & 2.9 \\
\hline 13 & Alcoholic beverages & 3.1 & Cakes & 2.4 & Savory snacks & 2.9 \\
\hline 14 & Non-processed meats & 2.8 & Cheese & 1.7 & Cheese & 2.1 \\
\hline 15 & Cheese & 1.9 & Processed meats & 1.7 & Yogurt & 2.0 \\
\hline 16 & Yogurt & 1.7 & Chocolate powder & 1.5 & Butter and margarine & 2.0 \\
\hline 17 & Processed meats & 1.6 & Nuts and seeds & 1.4 & Processed meats & 1.5 \\
\hline 18 & Chocolate powder & 1.3 & Yogurt & 1.4 & Sandwiches & 1.5 \\
\hline 19 & Sandwiches & 1.3 & Other preparations & 1.3 & Sugar & 1.3 \\
\hline 20 & Sugar & 1.2 & Rice & 1.2 & Pasta & 1.2 \\
\hline \multicolumn{2}{|l|}{ Total } & 91.2 & & 91.1 & & 91.7 \\
\hline
\end{tabular}

PCT: percentage of energy contribution in total energy intake.

participants contributed with $30.5 \%$ of the total energy intake from snacks: $11.8 \%$ cookies, $9.4 \%$ sugar-sweetened beverages, and $9.3 \%$ sweets and other desserts. Adolescents' food sources accounted for $14.9 \%$ of cookies, $10.9 \%$ of sweets and other desserts, and $9.5 \%$ of breads. Young adults' most common food sources were sugar-sweetened beverages $(10.5 \%)$, croquettes (9.0\%), and cookies (8.4\%).

An examination of the contribution of snacks to the overall sample per sex, lifestyle behaviors, and weight status revealed non-significant findings, but leading to a positive hypothesized direction for snack consumption, as shown in Table 4. Females (OR 0.93, 95\%CI 0.36-1.49) who met the current recommendations for PA (OR 0.75, 95\%CI 0.25-1.25) scored higher in the Brazilian Healthy Index-Revised $\left(2^{\text {nd }}\right.$ tercile of OR $0.67,95 \%$ CI $0.10-1.25$ and $3^{\text {rd }}$ tercile OR $0.88,95 \%$ CI $0.24-1.5)$ and had a higher intake of added sugars ( $3^{\text {rd }}$ tercile; OR 1.18, 95\%CI 0.46-1.90), showing a high intake of snacks. Overweight individuals were less likely to consume snacks (OR $-0.54,95 \% \mathrm{CI}-1.00$ to -0.08 ).

\section{DISCUSSION}

This study tried to understand the snacking behaviors of adolescents and young adults, as well as their daily energy, nutrients and food intakes. The findings indicated that snacking behaviors differed between adolescents and young adults. Thus, they offer valuable data to support health policies and behavioral-changing strategies to promote healthy weight status and lifestyle behaviors. Snacking can provide new opportunities to meet daily nutritional needs and numerous factors influence the intake by adolescents and young adults. ${ }^{9}$ Similar to our results, the Canadian Community Health Survey (CCHS) found a high prevalence of snacking among adolescents and young adults, i.e., more than $50 \% .{ }^{25}$ In contrast to the Canadian study, young adults have a slightly higher frequency of snack intake compared to adolescents. Young adults consumed more energy from snacks than adolescents, especially in mid-morning and night snacks. Alternatively, adolescents had more energy intake in afternoon-snacks. Moreover, 
Table 4 Snacks consumption, sex and lifestyle behaviors among adolescents ( $n=418)$ and young adults $(n=218)$. 2015 Health Survey of São Paulo with focus on Nutrition (2015 ISA-Nutrition).

\begin{tabular}{|c|c|c|c|}
\hline & \multicolumn{3}{|c|}{ Overall sample } \\
\hline & \multicolumn{2}{|c|}{ OR (SE) } & $95 \% \mathrm{Cl}$ \\
\hline \multicolumn{4}{|l|}{ Sex (reference: male) } \\
\hline Female & 0.9 & 0.3 & $0.4-1.5$ \\
\hline \multicolumn{4}{|l|}{ Weight status (reference non-overweight) } \\
\hline Overweight/obese & -0.5 & 0.2 & -1.0 to -0.1 \\
\hline \multicolumn{4}{|c|}{ PA (reference: does not meet recommendations for PA) } \\
\hline Meets the recommendations for PA & 0.8 & 0.3 & $0.3-1.3$ \\
\hline \multicolumn{4}{|l|}{ BHEI-R (reference: $1^{\text {st }}$ tercile) } \\
\hline $2^{\text {nd }}$ tercile & 0.7 & 0.3 & $0.1-1.3$ \\
\hline $3^{\text {rd }}$ tercile & 0.9 & 0.3 & $0.2-1.5$ \\
\hline \multicolumn{4}{|l|}{ Added sugars (reference: $1^{\text {st }}$ tercile) } \\
\hline $2^{\text {nd }}$ tercile & 0.4 & 0.3 & $-0.2-1.1$ \\
\hline $3^{\text {rd }}$ tercile & 1.2 & 0.4 & $0.5-1.9$ \\
\hline
\end{tabular}

BHEI-R: Brazilian Healthy Eating Index-Revised; 95\%Cl: 95\% confidence interval; OR: Odds Ratio; PA: physical activity; SE: standard error. Adjusted for age groups, educational level, per capita income, presence of chronic non-communicable diseases, race, screen time, sleeping time, and total energy and sodium intake. Significant values are bolded $(p<0.05)$.

adolescents and young adults obtained about one-quarter of their daily intake from breads, sugar-sweetened beverages, and sweets in snack times, corroborating another nationwide study conducted with 25,753 individuals older than 10 years, ${ }^{26}$ suggesting that these age groups are consuming these foods away from home. These results are important from the public health perspective. Snacks are related to the total energy intake and may differ according to some aspects, including the location where they are consumed. Therefore, this must be taken into account when thinking of health policies and behavior-change strategies. For example, evidence has shown that better cooking skills are associated with support in meal preparation and healthy eating, with great impact on diet quality.

Results suggest 36 to $256 \mathrm{kcal} /$ day intake in snacks. This variation of energy intake in snacks was associated with the time of the day when they were consumed: morning. afternoon, or night snack. This may suggest that energy intake from snack consumption can help reduce total daily energy intake. Evidence supports that other meals (i.e., breakfast, lunch, and dinner) were not associated with high-energy intake. This analysis allowed adjustment for potential confounders, such as total energy intake, as well as were looked for consumption time of snacks, being consistent with evidence showing that the energy yielded by snacks is not compensated for in the subsequent meal and leas consistently to higher total daily intake. ${ }^{27}$ Reports of mixed results on the effects of snacks on energy intake, can be attributed to broad variations in the definitions used for snacks, allowing this inconsistency. ${ }^{11,28}$ Concurrently, portion size served at one meal or in-between meals is positively associated with total energy intake. ${ }^{27}$ Hence, a low-energy intake in morning snacks and a higher-energy in afternoon snacks may influence energy intake at lunch and dinner, respectively, with improvement on overall diet quality. While further evidence is needed, consuming energy from snacks may help balance energy intake from other meals.

Evidence has shown that low-income families face some challenges on making healthy food choices, such as limited access to fruit and vegetables, whole-grains, and reduced-fat milk and dairy food sources within their food environment (at home and away from home). These challenges are not only limited to understanding what is (un)healthy food choices. For example, a qualitative study conducted with 83 adolescents of low-income status provided a simplistic view on healthy eating, i.e., dichotomizing foods into bad and good, with a prevalence of overweight and obesity of $28.9 \%$, with $42.1 \%$ of adolescents not considering their diet healthy, given that they report consuming food sources with sodium, saturated fats, and added sugars. ${ }^{29}$ The reasons for choosing these foods are not only related to their preferences, but also to access and availability, distance to food stores, cooking skills, and time available to prepare their meals. ${ }^{30}$ The complex and numerous challenges faced by low-income individuals required the development and implementation of innovative public health and behavior-changing strategies; the findings of the current study reinforce that further studies should try and understand the need for cultural tailoring of interventions found to be effective in making smart snack choices. 
One of the strength points of this study is the fact that it was population-based and conducted in a large urban center. It is well known that representative surveillance data are important to identify broader dietary patterns, but limitations should be taken into account. This analysis is based on a $24 \mathrm{hRs}$ and relies on self-reported data. As a cross-sectional study, a casual inference is not possible.

In conclusion, health policies and behavior-changing strategies aiming to improve the quality of snacks might broaden the aspects beyond energy-nutrient knowledge, reaching a more culture-tailored intervention. For example, focusing on the ability of choosing low-cost healthy foods and beverages and on learning to prepare healthy meals.

\section{Funding}

The Health Survey of São Paulo received financial support from the Department of Health of the City of Sáo Paulo (20130235.936-0); and the sub-sample of the Health Survey of São Paulo with focus on Nutrition received financial support from the São Paulo Research Foundation (process 2012/22113-9;
2017/05125-7). TSL was granted a scholarship for her undergraduate thesis (2017/23115-9), ACBL was a post-doctoral fellow from the São Paulo Research Foundation (2015/20852-7). RMF was granted a productivity scholarship from the National Council of Technological and Scientific Development (CNPq, 402674/2016-2; 301597/2017-0).

\section{Conflict of interests}

The authors declare there is no conflict of interests.

\section{Authors' contributions}

Study design: Lopes TS, Mello AV, Nogueira LR, Leme AC. Data collection: Lopes TS, Mello AV, Nogueira LR. Leme AC, Fisberg RM. Data analysis: Lopes TS, Fisberg RM. Manuscript writing: Leme AC. Manuscript revision: Lopes TS, Leme AC. Study supervision: Mello AV, Nogueira LR, Fisberg RM.

\section{Declaration}

The database that originated the article is available with the corresponding author.

\section{REFERENCES}

1. Biro FM, Wien M. Childhood obesity and adult morbidities. Am J Clin Nutr. 2010;91:1499S-505S. https://doi.org/10.3945/ ajcn.2010.28701b

2. Singh AS, Mulder C, Twisk JW, Mechelen W, Chinapaw MJ. Tracking of childhood overweight into adulthood: a systematic review of the literature. Obes Rev. 2008;9:47488. https://doi.org/10.1111/j.1467-789x.2008.00475.x

3. Leme AC, Thompson D, Dunker KL, Nicklas T, Philippi ST, Lopez $T$, et al. Obesity and eating disorders in integrative prevention programmes for adolescents: protocol for a systematic review and meta-analysis. BMJ Open. 2018;8:e020381. https://doi.org/10.1136/bmjopen-2017-020381

4. Haines J, Neumark-Sztainer D. Prevention of obesity and eating disorders: a consideration of shared risk factors. Health Educ Res. 2006;21:770-82. https://doi.org/10.1093/ her/cyl094

5. GBD 2015 Obesity Collaborators, Afshin A, Forouzanfar MH, Reitsma MB, Sur P, Estep K, et al. Health effects of overweight and obesity in 195 countries over 25 years. N Engl J Med. 2017;377:13-27. https://doi.org/10.1056/ nejmoa 1614362

6. Andrade SC, Previdelli AN, Cesar CL, Marchioni DM, Fisberg RM. Trends in diet quality among adolescents, adults and older adults: a population-based study. Prev Med Rep. 2016;4:391-6. https://doi.org/10.1016/j. pmedr.2016.07.010

7. Mertens E, Kuijsten A, Dofkova M, Mistura L, D’Addezio L, Turrini A, et al. Geographic and socioeconomic diversity of food and nutrient intakes: a comparison of four European countries. Eur J Nutr. 2019;58:1475-93. https://doi. org/10.1007/s00394-018-1673-6
8. Hicks K, Pitts SJ, Lazorick S, Fang X, Rafferty A. Examining the association between screen time, beverage and snack consumption, and weight status among Eastern North Carolina Youth. N C Med J. 2019;80:69-75. https://doi. org/10.18043/ncm.80.2.69

9. Krok-Schoen JL, Jonnalagadda SS, Luo M, Kelly OJ, Taylor CA. Nutrient intakes from meals and snacks differ with age in middle-aged and older Americans. Nutrients. 2019;11:1301. https://doi.org/10.3390/nu11061301

10. Loth KA, Tate A, Trofholz A, Orlet Fisher J, Neumark-Sztainer $D$, Berge JM. The contribution of snacking to overall diet intake among an ethnically and racially diverse population of boys and girls. J Acad Nutr Diet. 2020;120:270-9. https:// doi.org/10.1016/j.jand.2019.08.173

11. Marangoni F, Martini D, Scaglioni S, Sculati M, Donini LM, Leonardi F, et al. Snacking in nutrition and health. Int J Food Sci Nutr. 2019;70:909-23. https://doi.org/10.1080/096374 86.2019.1595543

12. Fisberg RM, Sales CH, Fontanelli MM, Pereira JL, Alves MC, Escuder MM, et al. 2015 Health Survey of Sao Paulo with Focus in nutrition: rationale, design, and procedures. Nutrients. 2018;10:169. https://doi.org/10.3390/nu10020169

13. D Sacks, Canadian Paediatric Society, Adolescent Health Committee. Age limits and adolescents. Paed Child Healt-Can. 2003;8:577-8. https://doi.org/10.1093/pch/8.9.577

14. Larson N, Laska MN, Neumark-Sztainer D. Do young adults value sustainable diet practices? Continuity in values from adolescence to adulthood and linkages to dietary behaviour. Public Health Nutr. 2019;22:2598-608. https:// doi.org/10.1017/s136898001900096x 
15. World Health Organization. Global recommendations on physical activity for health. Geneva: WHO; 2011.

16. Blanton CA, Moshfegh AJ, Baer DJ, Kretsch MJ. The USDA automated multiple-pass method accurately estimates group total energy and nutrient intake. J Nutr. 2006;136:2594-9. https://doi.org/10.1093/jn/136.10.2594

17. TBCA. Tabela Brasileira de Composição de Alimentos. São Paulo: Food Research Center; 2017.

18. Block G, Hartman A, Dresser C, Carroll M, Gannon J, Gardner L. A data-based approach to diet questionnaire design and testing. Am J Epidemiol. 1986;124:453-69. https://doi. org/10.1093/oxfordjournals.aje.a114416

19. Harttig U, Haubrock J, Knüppel S, Boeing H, EFCOVAL Consortium. The MSM program: web-based statistics package for estimating usual dietary intake using the Multiple Source Method. Eur J Clin Nutr. 2011;65:S87-91. https://doi.org/10.1038/ejcn.2011.92

20. Andrade SC, Previdelli AN, Marchioni DM, Fisberg RM. Evaluation of the reliability and validity of the Brazilian Healthy Eating Index Revised. Rev Saude Publica. 2013;47:675-83.

21. Nogueira LR, Fontanelli MM, Aguiar BS, Failla MA, Florindo $A A$, Leme $A C$, et al. Is the local food environment associated with excess body weight in adolescents in Sao Paulo, Brazil? Cad Saude Publica. 2020;36:e00048619. https:// doi.org/10.1590/0102-311×00048619

22. Craig $C L$, Marshall $A L$, Sjostrom M, Bauman AE, Booth $\mathrm{ML}$, Ainsworth BE, et al. International physical activity questionnaire: 12-country reliability and validity. Med Sci Sports Exerc. 2003;35:1381-95. https://doi.org/10.1249/01. mss.0000078924.61453.fb

23. Matsudo S, Araújo T, Matsudo V, Andrade D, Andrade E, Oliveira LC, et al. Questionário Internacional de Atividade
Física (IPAQ): estudo de validade e reprodutibilidade no Brasil. Rev Bras Ativ Fis Saude. 2001;6:5-18. https://doi. org/10.12820/rbafs.v.1n2p5-14

24. Barbosa Filho VC, Campos W, Lopes AS. Epidemiology of physical inactivity, sedentary behaviors, and unhealthy eating habits among Brazilian adolescents: a systematic review. Cien Saude Colet. 2014;19:173-93. https://doi. org/10.1590/1413-81232014191.0446

25. Vatanparast H, Islam N, Patil RP, Shafiee M, Smith J, Whiting S. Snack consumption patterns among Canadians. Nutrients. 2019;11:1152. https://doi.org/10.3390/nu11051152

26. Bezerra IN, Souza AM, Pereira RA, Sichieri R. Contribution of foods consumed away from home to energy intake in Brazilian urban areas: the 2008-9 Nationwide Dietary Survey. Вг J Nutr. 2013;109:1276-83. https://doi.org/10.1017/ s0007114512003169

27. Gilbert JA, Miller D, Olson S, St-Pierre S. After-school snack intake among Canadian children and adolescents. Can J Public Health. 2012;103:e448-52. https://doi.org/10.1007/ bf03405636

28. Njike VY, Smith TM, Shuval O, Shuval K, Edshteyn I, Kalantari V, et al. Snack food, satiety, and weight. Adv Nutr. 2016;7:86678. https://doi.org/10.3945/an.115.009340

29. Leme AC, Philippi ST, Silva EC. Association of Brazilian adolescents with healthy eating: knowledge, perceptions and food choices. Food Sci Nutr. 2011;2:1036-42. https:// doi.org/10.4236/fns.2011.29138

30. Utter J, Larson N, Laska MN, Winkler M, Neumark-Sztainer D. Self-perceived cooking skills in emerging adulthood predict better dietary behaviors and intake 10 years later: a longitudinal study. J Nutr Educ Behav. 2018;50:494-500. https://doi.org/10.1016/j.jneb.2018.01.021 